\title{
Faculty Development and Quality Assurance in the EU ERAMIS Project
}

\author{
http://dx.doi.org/10.3991/ijep.v2i3.2149 \\ A. Merceron ${ }^{1}$, J.M. Adam ${ }^{2}$, S. Luján-Mora ${ }^{3}$, M. Milosz ${ }^{4}$ and A. Toppinen ${ }^{5}$ \\ ${ }^{1}$ Beuth University of Applied Sciences, Berlin, Germany \\ 2 Pierre Mendès France University, Grenoble, France \\ ${ }^{3}$ University of Alicante, Alicante, Spain \\ ${ }^{4}$ Lublin University of Technology, Lublin, Poland \\ ${ }^{5}$ SavoniaUniversity of Applied Sciences, Savonia, Finland
}

\begin{abstract}
The aim of the ERAMIS project is to create a network of Masters degrees"Informatics as a Second Competence" in nine beneficiary universities of Kazakhstan, Kyrgyzstan and Russia. This contribution presents how faculty development is organized and quality assurance implemented inside this project.
\end{abstract}

Index Terms-Educational programs, Faculty Development, Informatics, Masters Network, Quality Assurance.

\section{INTRODUCTION}

The ERAMIS acronym stands for European-RussianCentral Asian Network of Master's degrees "Informatics as a Second Competence". This 3-year project is supported by the European Union (EU) in the Tempus scheme and involves five universities from five partner countries: Finland, France, Germany, Poland and Spain plus an external expert. It started in January 2010. Its aim is to create a Master degree "Informatics as a Second Competence" (ISC Master) in nine beneficiary universities located in Kazakhstan, Kyrgyzstan and Russia. This degree is intended for students having a Bachelor in social sciences, exact sciences or engineering but who did not graduate in computer science and therefore are non Information Technology (IT) specialists $[1,2,3]$. This Master is a geographical and disciplinary extension of two already existing Masters: one in the Pierre Mendes France University in Grenoble, France, the reference Master and, more recently, one in the Kyrgyz State National University, Bishkek, Kirghizstan $[4,5]$. The idea of the project rests on the following observation: Nowadays, organizations and enterprises demand more and more qualified employees able to apply correctly and usefully the Information and Communication Technologies (ICT). Specialists from all sectors need and must have additional ICT competences, not only be ICT-literate. Therefore, education systems all around the world must respond to this current demand.

In the first year of the project surveys were conducted in each of the future location of the Master to analyze the needs of the local industry regarding IT as well as the motivation of targeted students [6]. The result of these surveys as well as the two already existing Masters in Bishkek and Grenoble provided the basis to define the content of the curriculum of the ERAMIS Master. The curriculum was developed between the European Union teachers and teachers from the beneficiary universities and follows the guidelines of the Bologna process. Some beneficiary universities implement the master only for students coming from social sciences and others only for students coming from exact sciences or engineering. Beneficiary universities implementing the Master for both kinds of students mostly implement the Master in two institutes or faculties, so as to take the background of students better into consideration.

The Master contains core courses shared between all locations and elective courses that might differ between locations. All the syllabuses were fully described in English, following the common standard that was defined during the first meetings of the project. For the learning objectives and learning outputs description, we used the Revised Bloom's Taxonomy [7] [8]. The syllabus have been checked and verified by the independent expert involved in the project.

The definition of the curriculum has shown the need for faculty development of the beneficiary countries at several levels. First some courses are new in some universities, faculties need to acquire the knowledge to teach them later. Some courses are already taught in beneficiary universities, but for computer science specialists. Training is needed on how to teach these courses at a Master level for non computer science specialists. Third, the aim of this degree is to serve local companies. Training is needed to teach courses in a practical way. Finally the curriculum foresees that $20 \%$ of the courses should be taught in English. Faculty development has to take this aspect into account.

Furthermore the ERAMIS project intends to form a network of Masters allowing students and faculties to be mobile among the different geographical locations, and in the near future to deliver double diplomas. An additional aim of this training is to render competences and knowledge more homogenous among teachers of the different institutions. The network of Masters will work only if the local Masters keep the same standards. Therefore quality assurance is crucial.

This contribution presents how faculty development has been organizedand describes the main features of quality assurance that is implemented in the ERAMIS project.

\section{ORGANIZATION OF FACULTY DEVELOPMENT VIA MOBILITIES}

The major part of faculty development is organized through 17 courses taking place in the five partner univer- 
sities for faculties of the beneficiary countries. This training will be completed by a series of seminars to be given in 2012 by faculties of the partner universities taking place in the beneficiary universities. Thus faculty development is organized through mobilities in both ways. The present contribution focuses on the 17 courses, the main way of the mobilities.

\section{A. Putting up the offer}

TAB $\Lambda$ E I. Program OF THE MOBILITIES IN PARTNER UNIVERSITIES.

\begin{tabular}{|c|c|c|}
\hline Place & Courses & $\begin{array}{l}\text { Nb. train- } \\
\text { ees }\end{array}$ \\
\hline \multirow{4}{*}{$\begin{array}{l}\text { Beuth University } \\
\text { of Applied Sci- } \\
\text { ences, } \\
02 / 05 / 11 \text { - } \\
13 / 05 / 11\end{array}$} & Computer graphics & $4(R)$ \\
\hline & $\begin{array}{l}\text { Data Mining \& Data } \\
\text { Warehouse }\end{array}$ & $8(E)$ \\
\hline & Java Programming & $5(R / E)$ \\
\hline & $\begin{array}{l}\text { Software Architec- } \\
\text { ture }\end{array}$ & $5(E)$ \\
\hline \multirow{4}{*}{$\begin{array}{l}\text { Lublin University } \\
\text { of } \\
\text { Technology } \\
23 / 05 / 11 \text { - } \\
03 / 06 / 11 \\
06 / 06 / 11 \text { - } \\
17 / 06 / 11\end{array}$} & $\begin{array}{l}\text { Computer system } \\
\text { security }\end{array}$ & $7(E)$ \\
\hline & $\begin{array}{l}\text { Matlab in Engineer- } \\
\text { ing }\end{array}$ & $7(E)$ \\
\hline & $\begin{array}{l}\text { Mobile Systems } \\
\text { Development }\end{array}$ & $6(R)$ \\
\hline & $\begin{array}{l}\text { Object-Oriented } \\
\text { Software Engineer- } \\
\text { ing }\end{array}$ & $6(R)$ \\
\hline \multirow{3}{*}{$\begin{array}{l}\text { Pierre Mendès } \\
\text { France University } \\
\text { 13/06/11 - } \\
24 / 06 / 11\end{array}$} & $\begin{array}{l}\text { Artificial Intelligence } \\
\& \text {, Multi-agent Sys- } \\
\text { tems }\end{array}$ & $16(E / I)$ \\
\hline & $\begin{array}{l}\text { Human Machine } \\
\text { Interaction }\end{array}$ & $15(E / I)$ \\
\hline & Logic programming & $15(E / I)$ \\
\hline \multirow{3}{*}{$\begin{array}{l}\text { University of Ali- } \\
\text { cante } \\
13 / 06 / 11- \\
24 / 06 / 11\end{array}$} & $\begin{array}{l}\text { Content Management } \\
\text { Systems }\end{array}$ & $9(E)$ \\
\hline & $\begin{array}{l}\text { e-Business \& e- } \\
\text { Commerce }\end{array}$ & $9(E)$ \\
\hline & $\begin{array}{l}\text { Semi - structured } \\
\text { Documents }\end{array}$ & $9(E)$ \\
\hline \multirow{3}{*}{$\begin{array}{l}\text { Savonia University } \\
\text { of Applied Sci- } \\
\text { ences, } \\
24 / 10 / 11 \text { - } \\
04 / 11 / 11\end{array}$} & Cisco Academy & $15(E)$ \\
\hline & e-Learning & $15(E)$ \\
\hline & $\begin{array}{l}\text { Information System } \\
\text { Management }\end{array}$ & $15(E)$ \\
\hline
\end{tabular}

The European Universities gave a list of courses they offer according to the curriculum of the Master and to their respective strengths. Each beneficiary University expressed its wishes for the suggested courses. From those wishes we could determine the courses which would be organized and the Universities which would make them: we distributed the courses in a fair way among Universities, depending on the competences of each of them. So, 17 courses were opened and grouped in 5 sessions at the 5 European Universities of the consortium, see Table I. One course is 20 hours of teaching that should be completed with personal work.

Not all courses requested by Russian, Kazakh and Kyrgyz universities could take place. Were organized only those who were most in demand. According to the project, these training sessions will be completed by thematic seminars organized at the beneficiary universities. A number of these courses match exactly courses contained in the curriculum of the Master, but not all. Indeed the curriculum of the Master contains projects and internships in companies for students. Some courses offer knowledge useful for these educational activities.

Partner universities registered their candidates according to their competences, motivation and their involvement in the courses of the Master's degree program. The number of faculties following the training is shown on the right Table I. Each partner university has received one or two colleagues from each beneficiary university.

The courses' schedules at partner universities were different so that it was possible for a person to attend all courses offered in one place. In each place an attendee at to sign up for at least two courses. Some participants heard parts of some courses they did not register for.

As can be seen from Table I, the numbers of trainees per course were not big, so that each course was followed by faculties new to the field as well as by faculties knowing the field but wishing to learn other ways to teach it.

\section{A. Teaching in a practical way}

As stated in the introduction, one of the aims of the training organized at the partner universities was to stress practice. All trainings included theory, enlightening examples and practices. In most universities seminars were realized using a mixed method - lectures were interlaced with practical exercises. Complete handouts have been given quite often in electronic form. Practices have been conducted in labs and all facilities for the necessary software have always been provided. To emphasize further the practice of the courses, partners have organized various supplementary events.

At Beuth University of Applied Sciences an industry partner came to share with the participants his reasons for having close links with the Media Informatics department of this university.

The University of Alicante put the Content Management Systems Course into practice by loading all teaching materials in a specially structured repository.

At Lublin University of Technology (LUT) some small projects were carried out by participants using special software (Matlab, Visual Paradigm, Java ME SDK Platform 3.0). During the Computer system security course participants have created the ISP (Information Security Policy) document for a real organization. The most attractive element of this course was hiding information in images using the software developed at the Computer Science Institute of LUT. It was an example of practical usage of steganography.

Savonia University has given a presentation of the CDIO framework [9] to which it belongs. CDIO stands for Conceive Design Implement Operate. It is a world wide 


\section{SHORT PAPER \\ FACULTY DEVELOPMENT AND QUALITY ASSURANCE IN THE EU ERAMIS PROJECT}

network of universities which is particularly helpful to discuss and implements curricula as well as to develop relations and projects with industrial partners.

Practice of the Human Computer Interaction seminar at the University Pierre Mendès France in Grenoble included one full day hands-on devoted to discovering specific methods and tools for user interface evaluation. Two practical activities were organized: the first one was learning the adoption of an eye-tracking system to check where the user's eyes explore an interface; the second one was to carry out a real experiment using video camera and applying an experimentation protocol to compare the use of two different devices, a telephone and a laptop, presenting the same information.

\section{B. English.}

On one hand there is a language problem. Not all academics participating in the mobilities speak or even understand English fluently. Russian is a common language among the beneficiary countries, not among the partner countries. Not all partner universities can conduct their training in Russian. On the other hand, beneficiary countries have to conduct $20 \%$ of their teaching in English in this Master program, which is not an easy aim for a number of them to meet. They need extra motivation to increase their language skills in English.

The letter between brackets in Table I right column shows in which language courses have been hold: $R$ stands for Russian, $E$ for English and $E / I$ stands for English with an interpreter translating in Russian.

In some universities like in Beuth University of Applied Sciences an exchange student, Russian native speaker, had been hired to provide simultaneous translation of courses offered in English. However, the very first day, translation by a participant with good skills in English proved to be a much more superior solution. These translations usually gave raise to interesting and involved discussions between the participants, providing a spontaneous venue for exchange of views and experiences.

\section{TEACH THE Higher EdUCATION TEACHER}

Beside a good offer and proper course material there is a number of further constraints that influence in a decisive way the success of such a training involving mobilities.

\section{A. Internet access}

The trained teachers are mainly young teachers; however, some of them occupy administrative positions such as head of department or degree, faculty vice-deans, or are persons in charge of international activities or programs. They need and expect to follow their emails. Thus it is essential for them to have Internet access at the university and at the hotel as well. Failure to organize proper Internet access in advance can lead to frustration.

\section{B. Proper facilities}

Though most of the trainees came with their own laptop and worked on it, a few of them did not. Access to computers should be arranged for them. Also access to a dedicated place where trainees can meet, exchange or continue their personal work helps a lot for a successful training.

\section{Teaching styles}

Part of the training is to learn how to teach differently. As learners, the trainees are exposed to the teaching style of their European colleagues. However this should be completed by the visit of real classes where European colleagues teach to their regular students. Trainees like and learn form observing the working atmosphere of regular classes, even if the teaching is not conducted in English.

\section{Beyond the courses}

As already mentioned, part of the trainees are teachers with responsibilities in their own universities. They are interested in learning about the organization and the processes of the host university. Talks and discussions with contact persons in various positions in the host universities not only widen the horizon of all parties but can also be a good way of strengthening further relations between the involved institutions.

\section{E. Strengthening the network}

The aim of the ERAMIS project is to establish a network of Masters among the beneficiary and also partner universities. Personal relationships play an essential role in consolidating such a network. Gathering for two weeks participants at five different places of the project is an effective boost for the team spirit.

\section{F. Cultural differences and building confidence}

The training has been preceded by three coordination meetings of the project. The first coordination meeting took place in Grenoble, France, the second meeting took place in Saratov, Russia and the third meeting took place in Almaty, Kazakhstan. These meetings made some cultural differences clear, and stressed the importance of hospitality. The leader of the project, the team from the University of Grenoble, France was also well aware of the importance of hospitality through their former project with the Kyrgyz State National University, Bishkek, Kirghistan. Further it is well known that learning and teaching is boosted by mutual confidence [10]. All partner universities took this aspect into account, organizing get-together in the evening or on week-ends to foster an agreeable working atmosphere.

\section{G. Acquiring knowledge versus acquiring teaching methods}

As mentioned in the introduction, this training serves several aims in particular the aim of acquiring knowledge and the aim of acquiring teaching methods. Acquiring knowledge: Some courses in the master are new in some beneficiary universities, so teachers need to acquire wellfounded knowledge to teach those courses. Acquiring teaching methods: The same courses might not be new in other places but have to be taught to students with a different background, namely students whose Bachelor is not in Computer Science. Due to the manageable number of participants, trainees with these two kinds of needs were put into a single group. Therefore groups were not always homogeneous, which generated tensions. The speed and the focus when presenting the teaching material vary depending on the aim to serve. Serving both aims at once proved to be difficult in some of these non-homogeneous groups and has not always been solved in a way that could satisfy the two kinds of expectations. In a few courses the aim "acquiring knowledge" fell behind. The seminars organized in 2012 in beneficiary universities will help in solving this problem. 


\section{H. Train the trainer}

In such a faculty development program teachers of beneficiary countries become in some sense learners and teachers from partner universities become teachers for students who differ from their usual students. Not all teachers from the partner universities have followed some special training for this task [11]. However experience in teaching from both sides, partner and beneficiary, compensated that fact and made that the training was achieved with a high level of professionalism.

\section{QUALITY ASSURANCE}

According to the project objectives and to ensure quality during and after the project funding, we have created the Monitoring, Evaluation and Improvement Committee of theERAMIS network. This committee consists of one academic representative from each European university and our external expert.

\section{A. Visit of the partners}

The committee's first important mission was to visit all the partner Universities: one visit to the partners from Central Asia in April 2011, and the second one to the partners from Russia in May 2011. The main objective was to determine if the partners are ready to start the master in September 2011.

During the visits we have used the audit method based on the expected results and we have examined the following points:

1) Creation of the educational and administrative local teams.

2) Examination of the future Master's degree program model: verification that the compatibility constraints of the Master's degree program for ERAMIS network are respected, in other words: (a) Verification that the whole of the defined common courses are put in the same semester; (b) Verification that $20 \%$ of the courses are taught in English by teachers with sufficient knowledge of English.

3) Examination of the content of all the Master's degree program courses. This examination allowed us to detect the cases where the content of certain courses has been very much modified, the authors of these changes were very often not aware of the students' initial level at the launching of the Master's degree program and were not sufficiently sensitized to the fact that we are creating a network of Master's degree programs which are compatible among each other and are of the same level.

4) Verification of the training sessions at the European Universities. Every trainee was asked to choose at least one course that he or she attended at the European University and that he or she committed to teach in the future Master's degree program.

5) Discussion of the selection procedure for the future Master's candidates:The committee noted thatcertain Universities didn't have good knowledge of the Master's program potential audience and the process of selection was inadequate, as it privileged only the results of the entry exam, to the detriment of students' motivation which is essential in this type of Master's degree program. In these cases a different selection procedure was suggested by the Committee, which is based on English language test, an interview and, if need be, a written exam.

6) Information about the future Master's degree program intended for potential students: verification of the necessary material to inform students about the new Master's degree program: posters, booklets, leaflets, web pages created by the educational team. Certain documents missed some exact information, their quality could be improved by the Committee. Information operations intended for students took place at the partner Universities, certain were organized in the connexion with the Committee's visit.

7) Verification of the information put on ERAMIS project web site by the Universities: certain Universities didn't have any information about them, so the committee asked them to put information about their University and special information about the Master's degree program which was to open in September 2011.

8) Verification that the visited University hasa Moodle platform and the necessary competences to manage such a platform.

9) In the connexion of the monitoring committee's visit, the following questions were also resolved:

a) Information about the common collaborative platform set up in Grenoble and encouragement of the partners to supply the platform with the documents related to project and to fill in the time sheets which correspond to the work done for the project.

b) Information about double diplomas and experiences of Pierre Mendès France University in this field.

c) A first discussion about the way to evaluate the quality of the future Master's degree program.

These visits of the Monitoring, Evaluation and Improvement Committee helped to note that certain partners were not ready to launch the Master's degree program at the start of the academic year. The Committee gave advices and assistance to the visited partners and found solutions to almost all the arisen problems.

\section{B. Quality improvement and assurance during and beyond the project}

The following activities are planned to improve the quality of thenetwork:

1) Determination of the specific criteria for evaluation of the ISC Master's degree program in ERAMIS network. We are planning to create tests intended for student's evaluation of the common knowledge in computer science. These tests will be put on a web platform to which all the network students will have access. The tests results will give crietria for comparison of the Master's degree programs of the network and also to identify the eventual educational problems as well as the points to improve. The tests will be placed in the language of the courses of the Master's degree program. University of Alicante will set up this evaluation platform. 
2) Creation of a virtual survey to evaluate the courses: the same evaluation survey of the Master's education will be submitted to all the students of the network, via the web platform which is also planned for the tests.

3) The use of a Moodle platform of distance learning to create forums on every Master's program course: all the network teachers and European teachers who teach the same courses will exchange their experience of teaching in order to improve the courses next year all over the network. A reference e-learning platform, based at Savonia University (Kuopio, Finland), will provide the teachers of the network with specific spaces for every course of the Master's degree: the space will group all the educational documents produced inside the network for the course. All teachers giving this lecture will be able to share their teaching material and teaching experience with their colleagues.

The Master's degree ISC is designed for students beginning their studies in Computer Science. The teachers of the network are not used to teach Computer Science to this type of students, they may meet pedagogic problems. Exchanging experiences can help them to improve their lectures.

4) Evaluation of the results by the independent expert of the project: our independent expert knows perfectly this type of Master's degree program which we are creating in this project. He can also evaluate the quality of the courses' contents and identify the eventual pedagogical problems with student audience. Actually, numerous colleagues of the Master's degree program got used to teach students, specialists in computer science, and not specialists in other disciplines. This can be a pedagogical problem at the very beginning of the Master's program if the teachers overestimate their students.

5) Creation of a guide for strategy evolution and quality assurance of the ISC Master's degree program. It's planned to create a guide document which can be useful to the person in charge of the ISC master's degree program to improve regularly the Master's program. A work group will be created for the redaction of this document.

6) Setting up of an Improvement Council: in general, any international Master's degree program has an Improvement Council which takes place once a year. This council consists of the Master's teachers, students' representatives, and personalities from the industrial world who can hire, or take for an internship, students of the Master's program. After the precise presentation of the Master's degree program by the person in charge of the training, the council gives its opinion and advice to improve and update master's courses, to reinforce their professionalization in such a way to prepare students for their entry into the professional world.

7) Distance Learning platforms and exchanges among the teachers giving the same lecture: Moodle ELearning platforms are set up in all the Universities and provide the students with documents and educational activities. The Monitoring, Evaluation and Improvement Committee will have an access to each Moodle platform of the masters of the network.

The students of the network should be able to study electives courses provided by the other partner universities. This possibility will be available from September 2012.

\section{CONCLUSION}

The aim of the EU project is to create master degrees of informatics as a second competence in 9 beneficiary countries following and adapting a similar degree offered at the University Pierre Mendès France, Grenoble, France for over 20 years. The definition of the degree and the handbooks have shown that a faculty development program was necessary for teachers of beneficiary countries. Further quality assurance has to be implemented to make sure that all Masters follow and keep following the same standards.

In this contribution we have presented how such a faculty development program has been put in place in the project focusing on the part involving mobilities from beneficiary countries to partner countries, describing additional aspects that are essential in ensuring a successful faculty development inside projects similar to ERAMIS.All participants have expressed their overall satisfaction in their reports, even if they have mentioned aspects to improve. As already mentioned, the mobilities from the beneficiary towards the partners is to be completed in 2012 by mobilities from the partners towards the beneficiaries. For putting up the offer, we follow a similar process as described in this paper.

We have also described the quality assurancethat is being put in place to ensure continuation of the harmonization of the degrees inside the network, more details are given in [12]. Further the delivery of double diploma between universities, partner as well as beneficiary, is planed.

\section{ACKNOWLEDGMENT}

We thank all colleagues and students in partner universities who are not formally involved in the TEMPUSERAMIS project but who participated in organizing or conducting all events related to this project.

\section{REFERENCES}

[1] M. Milosz, U. Tukeyev, "ERAMIS Tempus Project - the Way to Building the European Russia Central Asia Academic Network". Materials of the International Conference "Current State and Future Perspectives of Higher Education in Kazakhstan - the Impact of the Tempus Programme", Almaty, 21-22 September 2010, pp. 329-333 (ISBN 978-601-263-093-0)

[2] S. Lujan-Mora, J-M. Adam, A. Merceron, M. Milosz and A. Toppinen, "Creating an international network of master degrees in computer science as a second competence", in Proceedings of the 4th International Conference of Education, Research and Innovation ICERI, Madrid (Spain), November 14-16, p. 2811-2815, ISBN: 978-84-615-3324-4, 2011.

[3] J-M Adam, S. Lujan-Mora, A. Merceron, M. Milosz and A. Toppinen, "European-Russian-Central Asian Network of Master's degree Informatics as a Second Competence", in Proceedings of EDUCON 2012: The IEEE International Education Engineering Conference, Marrakesh, Morocco, April 2012, pp. 722-729, ISBN 978-1-4673-1455-8. 


\section{SHORT PAPER \\ FACULTY DEVELOPMENT AND QUALITY ASSURANCE IN THE EU ERAMIS PROJECT}

[4] M. Miłosz M. and S. Luján-Mora, "TempusProject in Kyrgyzstan - the Case Study", Conference on Internationalization of Education in Russia - Contribution of TEMPUS programme. Astrachań, Russia, 19-20 April 2010, pp. 6-10 (ISBN 978-5-9926-03159-6)

[5] M. Miłosz, "Computer Science Study as a Second Education for Social Science Graduated - The Tempus Project JEP-262352005." Proceedings of Science-Practice Conference, pp. 9-13. Bishkek, Kyrgyzstan, 2009.06.15-18

[6] J-M. Adam, A. Merceron and M. Miłosz, "Using the Tuning Methodology in the Tempus ERAMIS Project" in Proceedings of the International Scientific and Education Congress "Science of the Future", 22-23 October 2010, Almaty, Kazakhstan, pp. 68-70 (ISBN 9965-29-525-5)

[7] Anderson, L., \& Krathwohl, D. E. (2001). "A Taxonomy for learning teaching and assessing: A revision of Bloom's taxonomy of educational objectives" [Abridged]. New York: Addison Wesley Longman, Inc.

[8] Pickard Mary J., "The new Bloom's Taxonomy: an overview for family and consumer sciences". Journal of Family and Consumer Sciences Education, Vol. 25, No. 1, Spring/Summer 2007, pp. 4555.

[9] Cdio http://www.cdio.org/ last access 26.10.2011.

[10] I.Hüter, "Die Bedeutung sozialer Erfahrungen für die Strukturierung des menschlichen Gehirns," in Neurodidaktik, U. Hermann (Ed.), Beltz Verlag, 2009, pp. 41-48. (ISBN 978-3-407-25511-2)

[11] M. Birkenbihl, Train the Trainer, Finanzbuch Verlag Gmbh, 2008.

[12] S. Lujan-Mora, J-M. Adam, A. Merceron, M. Milosz and A. Toppinen, "Quality Insurance in ERAMIS Network: The Assessment of Students", to appear in Proceedings of the 6th International Technology, Education and Development Conference INTED, Valencia, Spain, March 5-7, 2012.

\section{AUTHORS}

A. Merceron is a Professor at the Beuth University of Applied Sciences, Berlin, Germany, where she is the head of the Online Bachelor and Master Degrees "Informatics and Media". Her research interests are in the area of educational data mining and learning analytics. (merceron@beuth-hochschule.de).
J. M. Adam is Associate Professor in Computer Science at the Pierre Mendès-France University, Grenoble, France. He was the vice-dean of the Faculty of Human and Social Sciences from 2007 to 2011. Jean-Michel Adam is a researcher in the "Models and Technologies for Human Learning" (MeTAH) team of the Laboratory of Informatics of Grenoble (LIG). His research is particularly focused on software for Web-based interactive learning systems and on facial interactions in video-mediated education systems. Jean-Michel Adam is the coordinator of the European ERAMIS Tempus project (2010-2013). (Jean-Michel.Adam@imag.fr)

S. Lujan Mora is Lecturer of the Department of Software and Computing Systems at University of Alicante. He earned his Ph.D. in Computer Engineering at the University of Alicante (Spain) in 2005. His main research topics include web accessibility and usability, web applications, and e-learning (sergio.lujan@ua.es).

M. Miloszis a Senior Lecturer at the Lublin University of Technology, Lublin, Poland, where he is the head of the Department of Software Engineering and Databases, the deputy Director of the Institute of Computer Science and the deputy Dean of Electrical Engineering and Computer Science Faculty. His research interests are software engineering and project management. (marekm@cs.pollub.pl)

A. Toppinen is a Professor at Savonia University of Applied Sciences in Kuopio Finland. He is the head of Information Technology curriculum. His interest area is wireless sensor networks. (arto.toppinen@savonia.fi)

This work was supported in part by the EU Tempus Project ERAMIS 159025-TEMPUS-1-2009-FR-TEMPUS-JPCR. This article is an extended version of a paper presented at the International Conference IEEE EDUCON2012, held at University Mohammed V Souissi, Marrakesh, Morocco in the period of 17-20 April, 2012. Submitted, June, 8, 2012. Published as resubmitted by the authors on June, 24, 2012. 